\title{
Isolation and Identification of Salmonella spp. from Broiler Chicken Meat in Sri Lanka and their Antibiotic Resistance
}

\author{
T.S.P. Jayaweera ${ }^{1 *}$, H.A.D. Ruwandeepika ${ }^{1}$, V.K. Deekshit ${ }^{3}$, J.K. Vidanarachchi ${ }^{2}$, S.P. \\ Kodithuwakku², I. Karunasagar ${ }^{3}$ and H.W. Cyril ${ }^{2}$
}

Date Received: $18^{\text {th }}$ May 2020 / Date Accepted: $20^{\text {th }}$ July 2020

\begin{abstract}
Purpose : Salmonella infections continue to be a global problem with millions of humans and animal cases occurring annually. Broiler chicken plays a significant role causing Salmonella infections in Sri Lanka. Consumption of food contaminated with antimicrobial resistant Salmonella aggravates the problem. This study isolated, identified, and serotype the Salmonella spp. from broiler chicken meat in Sri Lanka and examined their antimicrobial susceptibility to be used in establishment of control measures.

Research Method: Isolation of Salmonella species from broiler chicken meat was done by conventional method of isolation followed by polymerase chain reaction (PCR) confirmation. All PCR confirmed isolates of Salmonella were serotype and then, isolates were tested for antibiotic susceptibility using disc diffusion assay followed by the detection of antibiotic resistance genes using PCR.

Findings : Broiler chicken meat in Sri Lanka is contaminated with Salmonella spp. at the prevalence of $11.6 \%$ and $8.9 \%$ of them carried hns and invA specific genes. Isolates were serotyped as Salmonella Typhimurium (47.8\%), Salmonella Enteritidis (26.1\%) and non typable (26.1\%). Three isolates were resistant to ampicillin. Intermediate resistance was shown to three antibiotics and all the isolates were sensitive to nine antibiotics. Majority (56.5\%) of Salmonella were sensitive to all the tested antibiotics. Prevalence of resistant genes for tetracycline, sulfonamides and aminoglycosides were within 4\%-26\%. None of the isolates except one (4\%) carried chloramphenicol resistance genes.

Originality/Value : Steps must be taken to minimize contamination of broiler chicken meat with Salmonella spp in Sri Lanka. Although, there is a low prevalence of antibiotic resistant isolates, its mere presence in broiler chicken is a warning signal of possibility of emergence of multidrug resistant strains.
\end{abstract}

Keywords: Salmonella, Isolation, PCR, Serotyping, Antibiotics, Sensitivity

\section{INTRODUCTION}

Salmonella is an important food borne pathogen which is the second most reason for the gastroenteritis after the Campylobacter spp. and distributed worldwide (Lamas et al., 2018). Nearly 100 million Salmonellosis cases have been reported annually worldwide, resulting 160,000 deaths every year. In 2015, around 100 000 confirmed cases of humans salmonellosis were reported in the European Union causing 126 deaths (Majowicz et al., 2010; EFSA, 2016). Aggravating the problem, consumption of food contaminated with a strain of Salmonella that is resistant to antimicrobials may lead to an infection in humans that cannot be successfully treated with antibacterial drugs (Kulasooriya et al., 2019). The major route of transmission of

\footnotetext{
1 Department of Livestock Production, Faculty of Agricultural Sciences, Sabaragamuwa University of Sri Lanka, Belihuloya, Sri Lanka.

sanjeewaprasadj@yahoo.com

2 Department of Animal Science, Faculty of Agriculture, University of Peradeniya, Peradeniya, Sri Lanka.

3 UNESCO Microbial Resources Center for Biotechnology, Faculty of Biological Sciences, Nitte University Center for Science Education and Research, Nitte (Deemed to be University), Deralakatte, Mangalore, India.
}

(1) ORCID http://orcid.org/0000-0002-8722-0529 
Salmonella from animals to humans is through contaminated food or foodstuffs such as eggs, egg products, poultry meat and dairy products (EFSA, 2015).

Salmonella is a facultative anaerobe belongs to the family Enterobacteriaceae, which consists of two species ( $S$. enterica and $S$. bongori). It is reported that exceeding 2600 serovars of Salmonella are causing gastroenteritis in both human and animals (Bhowmick et al., 2011; IssenhuthJeanjean et al., 2014; EFSA 2015; Ryan et al., 2017). S. enterica is further subdivided into six subspecies, namely; subsp. enterica, salamae, arizonae, diarizonae, houtenae and indica. S. enterica subspecies enterica consist of more than 1500 clinically important serovars. Salmonella Typhimurium and Salmonella Enteritidis are major such two serovars and they have been isolated predominantly from poultry (Lamas et al., 2018).

Understanding the characteristics of different strains of Salmonella is important for assessment of prevalence, survival and risk to human health. In this regard, phenotypic characteristics such as serotyping have been used for epidemiological investigation of Salmonella. Multiple typing methods are available including phenotypic biotyping, serotyping, phage-typing, antibiotic susceptibility testing, mass spectrometry and other nucleic acid based molecular techniques that can discriminate microorganisms up to the strain level based on phenotypic traits (Bhowmick et al., 2012; Karatug et al., 2018). Since poultry and poultry products are one of the major routes of transmission of Salmonella to humans, it is important to identify and serotype Salmonella strains isolated from poultry meat for diagnosis, treatment and also for the epidemiological surveillance of salmonellosis (Turki et al., 2014).

The gastroenteritis occurred due to nontyphoidal Salmonella serovars is usually self-limiting. But, application of antimicrobial therapy is required when it invades the other parts of the body. Emergence of antimicrobial resistance among nontyphoidal Salmonella serovars to medically important antibiotics has been documented during the last two decades. However, the resistance varied among the serotypes and to different antibiotics. It is reported that $S$. enterica Typhimurium demonstrate advanced resistance to frequently used antibiotics than $S$. Enteritidis, among all the Salmonella serotypes (Barilli et al., 2018).

Due to lack of funding and technical facilities, there is poor understanding about the causes of food-borne infections such as Salmonellosis in Sri Lanka. However, according to DAPH, 2015 , broiler chicken meat production as well as consumption in the country show a rapid increase during the past few years. It is also reported that the contribution of broiler chicken meat and egg production to the livestock sector of Sri Lanka is around $70 \%$. Previous studies conducted in Sri Lanka have found contamination of poultry with Salmonella, Campylobacter and E. coli (Kamalika et al., 2008; Dissanayake et al., 2008; Kottawatta et al., 2017). Furthermore, resistance to commonly used antimicrobials was found in many of the bacterial isolates taken during these studies.

Lack of molecular level identification, not performing serotyping and lack of molecular level investigations on antibiotic resistance of Salmonella were the major precincts of the earlier studies. Thus this study was formulated to isolate, identify, serotype and to detect the vulnerability to commonly used antibiotics along with the detection of antibiotic resistance genes corresponding to phenotypic resistance in Salmonella spp. found in the broiler meat locally produced in Sri Lanka.

\section{MATERIALS AND METHODS}

Isolation of Salmonella species from broiler chicken meat was done by conventional method of isolation followed by polymerase chain reaction (PCR) confirmation.

\section{Collection of samples}

260 broiler chicken meat samples were randomly obtained from different locations of the country from 2012 August to 2013 August. All the samples were immediately stored in ice and 
transported to the laboratory and analyzed as soon as possible following the collection. Laboratory investigations to isolate followed by identification of Salmonella was performed at the Livestock laboratory of the Faculty of Agricultural Sciences of the Sabaragamuwa University of Sri Lanka and molecular characterization of the isolates was performed at the Laboratory of UNESCO MIRCEN for Marine Biotechnology, Division of Infectious Biology, Nitte University Centre of Science Education and Research, Mangalore.

\section{Isolation of Salmonella by conventional method}

Conventional method recommended by FDA Bacteriological Analytical Manual was used to isolate Salmonella from broiler chicken meat samples (Andrews and Hammack, 2011). Briefly, $225 \mathrm{ml}$ lactose broth was used to homogenize a $25 \mathrm{~g}$ portion of the meat sample for 2 minutes using a stomacher (Bag mixer ${ }^{\mathrm{R}} 400$, Interscience International, France). This mixture was incubated for 24 hours at $37^{\circ} \mathrm{C}$ as the pre-enrichment step. Then $1 \mathrm{~mL}$ each of pre-enriched sample was added to $10 \mathrm{~mL}$ each of selinite cystine broth and tetrathionate broth (TTB), while $10 \mathrm{~mL}$ of Rappaport-Vassiliadis broth was used to add 0.1 $\mathrm{mL}$ of the pre-enriched sample. The inoculated selenite cystine and tetrathionate broths were incubated at $37^{\circ} \mathrm{C}$ for 24 hours, while Rappaport Vassiliadis broth was incubated at $43^{\circ} \mathrm{C}$ in a water bath for 24 hours. Loop full each from these broths was streaked on the selective media of Hektoen Enteric Agar and Bismuth sulphite Agar together with Xylose-Lysine-Desoxycholate agar and incubated at $37^{\circ} \mathrm{C}$ for 24 hours.

\section{Biochemical Identification}

Identification of Salmonella spp was performed through a series of biochemical tests using colonies grown in selective media. Minimum of five typical colonies from each of the selective agars were used for the study. Indole test, triple sugar iron test, Simmons citrate test, urease test, methyl red and Voges-Proskauer test (MR-VP) were used as biochemical tests. To preserve the biochemically confirmed isolates, $40 \%$ glycerol was used. Then the isolates were stored at $-80^{\circ} \mathrm{C}$ to be used in further analyses.

\section{Confirmation of Isolates by PCR}

Salmonella isolates were further confirmed by PCR, targeting Salmonella specific invasion gene invA (284 bp) (Jones et al., 1993) and the gene encoding a DNA binding protein hns (152 bp) (Rahn et al., 1992). N-cetyl-N,N,Ntrimethylammonium bromide (CTAB) method was used for DNA extraction (Ausubel et al., 1992). According to the protocol described by Bhowmick et al., (2011), a thermal cycler (BioRad, PTC-200, CA, USA) was used to carry out PCR reactions (Table 01). Agarose gel $(2 \%)$ was used to resolve the PCR products and stained with ethidium bromide $(0.5 \mu \mathrm{g} / \mathrm{ml})$ followed by photographed and analyzed using gel documentation system (Gel Doc ${ }^{\mathrm{TM}}$ EZ Gel Documentation System, BioRad, USA).

\section{Serotyping of Salmonella}

All PCR confirmed isolates (23) of Salmonella were serotyped at the Reference Centre for Salmonella and E. coli at the Central Research Institute, Himachal Pradesh, India.

\section{Detection of Antibiotic Sensitivity Using Disc Diffusion Method}

Following isolation and identification, Salmonella isolates were tested for antibiotic susceptibility by means of the disc diffusion assay as explained by Bauer et al., (1966). Antibiotic discs such as Nitrofurantoin $(30 \mu \mathrm{g})$ (NIT), cefotaxime $(300 \mu \mathrm{g})(\mathrm{CTX})$, nalidixic acid $(30 \mu \mathrm{g})(\mathrm{NA})$, piperacillin (10/100) (PIT), chloramphenicol $(30 \mu \mathrm{g})(\mathrm{C})$, co-trimoxozole $(25 \mu \mathrm{g})(\mathrm{COT})$, ciprofloxacin $(5 \mu \mathrm{g})(\mathrm{CIP})$, tetracycline $(30 \mu \mathrm{g})$ (TE), meropenem (10 $\mu \mathrm{g})$ (MRP), kanamycin $(30 \mu \mathrm{g})(\mathrm{K})$ and Gentamycin $(10 \mu \mathrm{g})(\mathrm{GEN})$ were used for the antibiogram test according to manufacturer's (Indian HiMedia Laboratories Pvt Ltd) guidelines. In order to prepare a lawn, a Salmonella culture grown-up for 10-12 h in $5 \mathrm{ml}$ Mueller-Hinton broth attuned to $0.5 \mathrm{McF}$ arland (Indian HiMedia Laboratories Pvt Ltd) was poured on well-dried Mueller-Hinton agar (Indian HiMedia Laboratories Pvt Ltd). 
Table 01: $\quad$ Primers used for the confirmation of Salmonella isolates

\begin{tabular}{ccccc}
\hline Gene & Gene description & Primer sequences (5'-3') & $\begin{array}{c}\text { Product } \\
\text { size (bp) }\end{array}$ & Reference \\
\hline Hns & $\begin{array}{l}\text { Histone like nucleoid } \\
\text { structuring gene }\end{array}$ & $\begin{array}{l}\text { F-TACCAAAGCTAAACGCGCAGCT } \\
\text { R-TGATCAGGAAATCTTCCAGTTGC }\end{array}$ & 152 & $\begin{array}{c}\text { Jones } \text { et al., } \\
1993\end{array}$ \\
$\begin{array}{l}\text { Gene encoding the } \\
\text { invasion-associated } \\
\text { protein }\end{array}$ & $\begin{array}{c}\text { F-GTGAAATTATCGCCACGTTCGGGCAA } \\
\text { R-TCATCGCACCGTCAAAGGAACC }\end{array}$ & 284 & $\begin{array}{c}\text { Rahn } \text { et al., } \\
1992\end{array}$ \\
\hline
\end{tabular}

The antibiotic discs were placed on the surface of the medium after gently air drying in a laminar flow and incubated for $16-18$ hours at $37{ }^{\circ} \mathrm{C}$ until a clear zone is obtained and interpretation of the results were done as described by Clinical and Laboratory Standards Institute (CLSI), USA guidelines. As the control strain, E. coli ATCC 22592 was used.

\section{Presence of antimicrobial resistance genes}

In order to detect the genes responsible for antimicrobial resistance in the 23 isolates of Salmonella, specific genes ensuing resistance to common antibacterials were tested by PCR using their respective primers. The genes tet $A$, tet $B$, tet $C$, tet $D$, tet $E$, and $\operatorname{tet} G$ were used to $\operatorname{detect}$ the resistance for tetracyclines while sul1, sul2, and sul3 were used for sulfonamides. Resistance to chloramphenicol was checked using catl, cat2, cat3, cmlA, cmlB and floR genes and aph (3)11a, aac (3) $11 a$ and aac6 were used for aminoglycosides. DNA extraction was carried out as described earlier following the protocol by Ausubel et al., (1992). A thermal cycler (Bio-Rad, PTC-200, Hercules, CA) was used to carry-out reactions and PCR conditions and primer sequences were maintained as described in previous studies (Ma et al., 2007) (Table 02).

\section{RESULTS AND DISCUSSION}

Isolation, identification, confirmation and serotyping of Salmonella from broiler chicken meat samples

Isolation of Salmonella species from broiler chicken meat was done by conventional method of isolation followed by polymerase chain reaction (PCR) confirmation. Then the isolates were subjected to serotyping.

Out of 260 broiler chicken meat samples, 30 isolates $(11.6 \%)$ were identified as Salmonella by means of conventional methods. Out of that 30 isolates, 23 isolates ( $89 \%$ ) were confirmed as Salmonella by PCR.

Though there is a paucity of literature on isolation of Salmonella from broiler chicken meat in Sri Lanka, few studies have shown Salmonella as a common organism isolated from different food commodities in the country. Kamalika et al., (2008) found that the prevalence of Salmonella in captured shrimps and cultured shrimps in Sri Lanka was $14.4 \%$ and $11.1 \%$, respectively. Ariyawansa et al., (2016) investigated the quality of the fish in western province of Sri Lanka and revealed that $5.6 \%$ of the fish samples were contaminated with Salmonella. It indicates the higher prevalence of Salmonella spp. in broiler chicken compared to that of fish. Their study also showed that $50 \%$ of harbor basin water samples and $20 \%$ ice samples were heavily contaminated with Salmonella spp.

High prevalence $(40.6 \%)$ of Salmonella in broiler chicken meat from vendor shops in Sri Lanka was discovered by Thilakarathne et al., (2012). A higher presence of Salmonella has been found in broiler chicken meat than that was found in the present study. Using conventional method, Kulasooriya et al., (2019) found that the contamination level with Salmonella spp. were $10 \%$ and $17 \%$ in chilled raw broiler chicken meat and frozen broiler chicken meat respectively. These findings are also in agreement with the results of the present study. 
Table 02: Primers used for the detection of presence of antibiotic resistance genes.

\begin{tabular}{|c|c|c|c|c|c|c|}
\hline $\begin{array}{l}\text { Resistance } \\
\text { gene }\end{array}$ & & Nucleotide sequence & $\begin{array}{l}\text { Product } \\
\text { size (bp) }\end{array}$ & $\begin{array}{c}\text { Annealing } \\
\text { temperature }\left({ }^{\circ} \mathrm{C}\right)\end{array}$ & $\begin{array}{l}\text { Code of } \\
\text { antibiotic }\end{array}$ & Reference \\
\hline tetA & $\begin{array}{l}\mathrm{F} \\
\mathrm{R}\end{array}$ & $\begin{array}{l}\text { TTGGCATTCTGCATTCACTC } \\
\text { GTATAGCTTGCCGGAAGTCG }\end{array}$ & 494 & 55 & TET & $\begin{array}{l}\text { Ma et al., } \\
\text { (2007) }\end{array}$ \\
\hline tet $B$ & $\begin{array}{l}\mathrm{F} \\
\mathrm{R}\end{array}$ & $\begin{array}{l}\text { CAGTGCTGTTGTGTCATTAA } \\
\text { GCTTGGAATACTGAGTGTAA }\end{array}$ & 571 & 55 & TET & $\begin{array}{l}\text { Ma et al., } \\
\text { (2007) }\end{array}$ \\
\hline tet $C$ & $\begin{array}{l}\mathrm{F} \\
\mathrm{R}\end{array}$ & $\begin{array}{l}\text { CTTGAGAGCCTTCAACCCAG } \\
\text { ATGGTCGTCATCTACCTGCC }\end{array}$ & 418 & 55 & TET & $\begin{array}{l}\text { Ma et al., } \\
\text { (2007) }\end{array}$ \\
\hline tetD & $\begin{array}{l}\mathrm{F} \\
\mathrm{R}\end{array}$ & $\begin{array}{l}\text { GCTCGGTGGTATCTCTGCTC } \\
\text { AGCAACAGAATCGGGAACAC }\end{array}$ & 546 & 55 & TET & $\begin{array}{l}\text { Ma et al., } \\
(2007)\end{array}$ \\
\hline tetE & $\begin{array}{l}\mathrm{F} \\
\mathrm{R}\end{array}$ & $\begin{array}{l}\text { TATTAACGGGCTGGCATTTC } \\
\text { AGCTGTCAGGTGGGTCAAAC }\end{array}$ & 544 & 55 & TET & $\begin{array}{l}\text { Ma et al., } \\
(2007)\end{array}$ \\
\hline $\operatorname{tet} G$ & $\begin{array}{l}\mathrm{F} \\
\mathrm{R}\end{array}$ & $\begin{array}{l}\text { GCTCGGTGGTATCTCTGCTC } \\
\text { CAAAGCCCCTTGCTTGTTAC }\end{array}$ & 550 & 55 & TET & $\begin{array}{l}\text { Ma et al., } \\
(2007)\end{array}$ \\
\hline Sull & $\begin{array}{l}\mathrm{F} \\
\mathrm{R}\end{array}$ & $\begin{array}{l}\text { TTTCCTGACCCTGCGCTCTAT } \\
\text { GTGCGGACGTAGTCAGCGCCA }\end{array}$ & 793 & 55 & $\mathrm{COT}$ & $\begin{array}{l}\text { Ma et al., } \\
\text { (2007) }\end{array}$ \\
\hline Sul2 & $\begin{array}{l}\mathrm{F} \\
\mathrm{R}\end{array}$ & $\begin{array}{l}\text { CCTGTTTCGTCCGACACAGA } \\
\text { GAAGCGCAGCCGCAATTCAT }\end{array}$ & 667 & 55 & COT & $\begin{array}{l}\text { Ma et al., } \\
\quad(2007)\end{array}$ \\
\hline Sul3 & $\begin{array}{l}\mathrm{F} \\
\mathrm{R}\end{array}$ & $\begin{array}{l}\text { ATGAGCAAGATTTTTGGAATCGTAA } \\
\text { CTAACCTAGGGCTTTGGTATTT }\end{array}$ & 792 & 55 & COT & $\begin{array}{l}\text { Ma et al., } \\
\text { (2007) }\end{array}$ \\
\hline cat1 & $\begin{array}{l}\mathrm{F} \\
\mathrm{R}\end{array}$ & $\begin{array}{l}\text { AACCAGACCGTTCAGCTGGAT } \\
\text { CCTGCCACTCATCGCAGTAC }\end{array}$ & 549 & 55 & CHL & $\begin{array}{l}\text { Zhao et al., } \\
\text { (2001) }\end{array}$ \\
\hline cat2 & $\begin{array}{l}\mathrm{F} \\
\mathrm{R}\end{array}$ & $\begin{array}{l}\text { AACGGCATGAACCTGAA } \\
\text { ATCCCAATGGCATCGTAAAG }\end{array}$ & 547 & 55 & CHL & $\begin{array}{l}\text { Ma et al., } \\
\text { (2007) }\end{array}$ \\
\hline cat3 & $\begin{array}{l}\mathrm{F} \\
\mathrm{R}\end{array}$ & $\begin{array}{l}\text { ATCGGCATCGGTTACCATGT } \\
\text { ATCCCCTTCTTGCTGATATT }\end{array}$ & 310 & 55 & $\mathrm{CHL}$ & $\begin{array}{l}\text { Ma et al., } \\
\quad(2007)\end{array}$ \\
\hline $\mathrm{cmlA}$ & $\begin{array}{l}\mathrm{F} \\
\mathrm{R}\end{array}$ & $\begin{array}{l}\text { GGCCTCGCTCTTACGTCATC } \\
\text { GCGACACCAATACCCACTAGC }\end{array}$ & 662 & 55 & CHL & $\begin{array}{l}\text { Ma et al., } \\
\text { (2007) }\end{array}$ \\
\hline$c m l B$ & $\begin{array}{l}\mathrm{F} \\
\mathrm{R}\end{array}$ & $\begin{array}{l}\text { ACTCGGCATGGACATGTACT } \\
\text { ACGGACTGCGGAATCCATAG }\end{array}$ & 840 & 55 & $\mathrm{CHL}$ & $\begin{array}{l}\text { Ma et al., } \\
(2007)\end{array}$ \\
\hline floR & $\begin{array}{l}\mathrm{F} \\
\mathrm{R}\end{array}$ & $\begin{array}{l}\text { ATGACCACCACACGCCCCG } \\
\text { AGACGACTGGCGACTTCTTCG }\end{array}$ & 198 & 55 & CHL & $\begin{array}{l}\text { Ma et al., } \\
\text { (2007) }\end{array}$ \\
\hline$a a c$ (3) $11 a$ & $\begin{array}{l}\mathrm{F} \\
\mathrm{R}\end{array}$ & $\begin{array}{l}\text { CGGCCTGCTGAATCAGTTTC } \\
\text { AAAGCCCACGACACCTTCTC }\end{array}$ & 439 & 55 & GEN & $\begin{array}{l}\text { Ma et al., } \\
\text { (2007) }\end{array}$ \\
\hline $\operatorname{aph}(3) 11 a$ & $\begin{array}{l}\mathrm{F} \\
\mathrm{R}\end{array}$ & $\begin{array}{l}\text { TCTGAAACATGGCAAAGGTAG } \\
\text { AGCCGTTTCTGTAATGAAGGA }\end{array}$ & 582 & 55 & GEN & $\begin{array}{l}\text { Ma et al., } \\
\text { (2007) }\end{array}$ \\
\hline aac6 & $\begin{array}{l}\mathrm{F} \\
\mathrm{R}\end{array}$ & $\begin{array}{l}\text { TTGGACGCTGAGATATATGA } \\
\text { GCTCCTTTTCCAGAATACTT }\end{array}$ & 476 & 55 & GEN & $\begin{array}{l}\text { Ma et al., } \\
\text { (2007) }\end{array}$ \\
\hline
\end{tabular}

Tetracyclines (tetA, tetB, tetC, tetD, tetE, and tet $G$ ), sulfonamides (sul1, sul2, and sul3), chloramphenicol (cat1, cat2, and cat3, cmlA, $\mathrm{cmlB}$, floR) and aminoglycosides (aph (3)11a, aac (3)11 a and aac6

Though the prevalence of Salmonella in broiler chicken in Sri Lanka was found as $11.6 \%$ by conventional methods in the present study, higher prevalence have been reported in other countries, such as $36.5 \%$ in Belgium (Uyttendaele et al., 1999), 35.8\% in Spain (Dominguez et al., 2002), $35.5 \%$ in Malaysia (Rusul et al., 1996), 34\% in Turkey (Yildirim et al., 2011) and 39.5\% in Greece (Zdragas et al., 2012). Further, a higher incidence $(88.5 \%)$ of Salmonella has been discovered in broiler chicken meat in Malaysia (Nidaullah et al., 2017). In South Africa too, Salmonella has been identified as the most prevalent pathogen in broiler chicken meat (Magwedere et al., 2015). It has been reported that the prevalence of
Salmonella in poultry meat in Thailand was $84 \%$. (Bodhidatta et al., 2013; Chotinun et al., 2014). The reasons for the above different observations could be various factors related to the handling process and meat processing activities in different countries. Similar to the present findings, 17.91\% prevalence of Salmonella in broiler chicken meat was reported in Iran (Jalali et al., 2008). The lower contamination level found in our present study could be a result of quality improvements achieved in meat processing activities in the country in the recent past.

Many studies have demonstrated the higher prevalence of Salmonella in other livestock 
species as well. Farzan et al., (2010) reported $31.5 \%$ prevalence of Salmonella in swine. Pork and beef also play a great role in causing salmonellosis apart from poultry meat (Litrup et al., 2010; Osman et al., 2014; Abatcha et al., 2018).

Two different pairs of primers were used to confirm isolates as Salmonella, targeting hns (DNA binding protein encoding gene) and invA genes. The isolates were confirmed as Salmonella only when they are positive for both $h n s$ (152 bp) (Figure 1A) and invA (284 bp) (Figure 1B) genes.

Though the conventional identification of Salmonella is an important tool for speciation of the isolates, molecular confirmation is necessary to complete the identification process. A study to compare the conventional isolation methods vs molecular identification procedure to detect Salmonella in broiler chicken meat has revealed that prevalence of Salmonella in meat samples was $12 \%$ in molecular method whereas it was $22 \%$ in the conventional method (Ibrahim et al., 2014). Use of PCR by targeting the sequences of $h n s$ and invA genes for rapid detection of Salmonella has been proven earlier too (ElSebay et al., 2017). As a unique sequence to this genus available in fragment of inv $A$ gene, it has been verified as a precise PCR target (Rahn et al., 1992). The current study has shown the presence of invA gene in all the isolates and the finding is in agreement with other studies that detected inv $A$ in all the isolates (100\%) obtained from chicken samples (Abd El Tawwab et al., 2013; Cossi et al., 2013; Karatug et al., 2018). A protein responsible for invasion into the host cells is located in the inner membrane of the Salmonella bacterium and invA gene encodes that protein. As it is highly specific to the bacterium, that gene can be used to detect all Salmonella species with more accuracy (Shanmugasamy et al., 2011; Karmi 2013). Hence, invA has been now proved as an international standard specific gene for the identification of genus Salmonella. The oligonucleotide sequence of hns gene used here was designed by Jones et al., (1993) from the regions where the $S$. Typhimutium nucleotide sequences mismatch with the hns gene in other members of the Enterobacterieceae to have specific primer for Salmonella. This study also used these two sets of genes for confirming the Salmonella isolates as they have the ability to detect Salmonella with high accuracy.

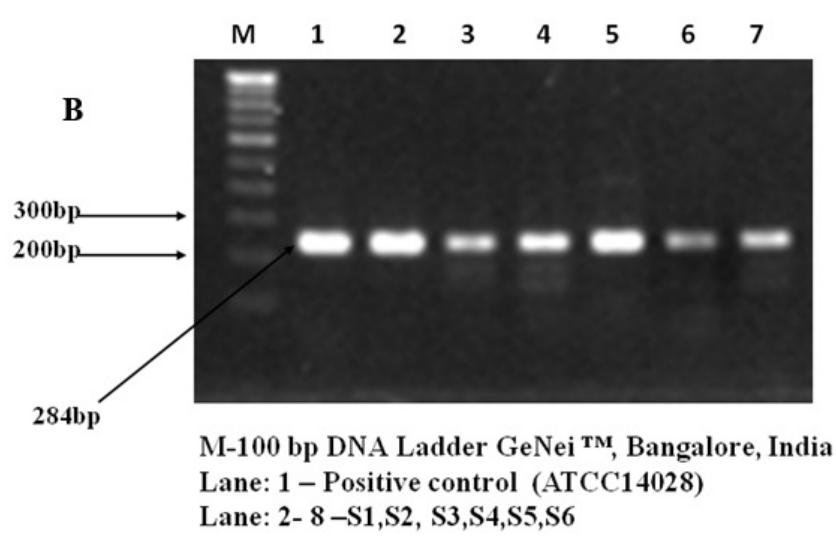

Figure 01: $\quad$ PCR amplification of $h n s$ gene (A) and invA gene (B) of Salmonella isolates.

Table 03: $\quad$ Serotyping of Salmonella isolates.

\begin{tabular}{lc}
\hline \multicolumn{1}{c}{ Serotypes } & Isolate number \\
\hline Salmonella Typhimurium & $\mathrm{S} 1, \mathrm{~S} 2, \mathrm{~S} 4, \mathrm{~S} 6, \mathrm{~S} 8, \mathrm{~S} 9, \mathrm{~S} 11, \mathrm{~S} 16, \mathrm{~S} 19, \mathrm{~S} 21, \mathrm{~S} 23$ \\
Salmonella Enteritidis & $\mathrm{S} 3, \mathrm{~S} 10, \mathrm{~S} 15, \mathrm{~S} 17, \mathrm{~S} 20, \mathrm{~S} 22$ \\
Non typable Salmonella spp. & $\mathrm{S} 5, \mathrm{~S} 7, \mathrm{~S} 12, \mathrm{~S} 13, \mathrm{~S} 14, \mathrm{~S} 18$ \\
\hline
\end{tabular}


All the PCR confirmed isolates were serotyped and 11 out of $23(47.8 \%)$ were identified as Salmonella Typhimurium and 6 isolates $(26.1 \%)$ were identified as Salmonella Enteritidis. The remaining six (26.1\%) PCR confirmed isolates were not serotyped. The results of serotyping of Salmonella isolates are given in Table 3.

Weerasooriya et al., (2008) found that the most common serovar of Salmonella found in broiler chicken meat in Sri Lanka was $S$. Typhimurium while Wijemanne et al., (2008) revealed that $S$. Enteritidis as the most common serovar in poultry breeder farms in Sri Lanka. Kottawatta et al., (2014) reported 9\% prevalence of Salmonella in broiler chicken in Sri Lanka with $S$. Typhimurium as the common serovar. The present study also found that 11 isolates out of 23 were $S$. Typhimurium and only 6 out of 23 isolates were $S$. Enteritidis. Hence, the current study has also shown that the prominant Salmonella serovar in Sri Lanka is $S$. Typhimurium which is inaccordance with many of the the previous studies.

Previous studies have obtained different outcomes on prevalence of Salmonella serovars in poultry meat in many other countries as well. Mir et al., (2015) reported that Salmonella Enteritidis was the foremost serotype followed by Salmonella Typhimurium. Parvej et al., (2016) also reported the higher prevalence of Salmonella Enteritidis in Bangladesh. Those findings were in contrast with the current study as Salmonella Typhimurium was found as the most prominent serotype in Sri Lanka. In parallel to the present findings, Abdellah et al., (2009) reported the predominance (40\%) of $S$. Typhimurium in poultry samples in Morocco. El-Aziz (2013) found that the prevalence of $S$. Typhimurium in chicken meat was 44\% in Egypt. Findings of Moawad et al., (2017) isolating Salmonella from chicken and beef are also in line with the current study, which showed that $S$. Typhimurium is the most common Salmonella serovar in broiler chicken meat. A study in Spain has shown that the $S$. Typhimurium being the most prevalent (Lamas et al., 2016). High prevalence of both $S$. Typhimurium and $S$. Enteritidis has been discovered from USA meat industry as well (Andino and Hanning, 2015). It is also in agreement with the current study as it also showed the presence of $S$. Enteritidis as the second most common organism found in broiler chicken meat in Sri Lanka.

\section{Detection of antibiotic sensitivity using disc diffusion method}

Antibiotic sensitivity testing revealed that three (13.5\%) isolates (S5, S6 and S18) were resistance to ampicillin and five $(21.7 \%)$ isolates (S2, S10, S12, S21, S22) have intermediate resistance to ampicillin. Seven (30.5\%) isolates (S6, S10, S11, S12, S20, S21, S22) showed intermediate resistance for nitrofurantoin (NIT) while all the other isolates were sensitive to the same antibiotic. Only one $(4.3 \%)$ isolate (S20) exhibited intermediate resistance to cefotaxime (CTX) while all the other isolates were sensitive to that. All the isolates were sensitive to NA, C, PIT, COT, CIP, TE, MRP, K and G. The positive massage obtained by the results of this study was that $56.5 \%(13 / 23)$ isolates were sensitive to all the tested antibiotics (Table 04).

\section{Presence of antimicrobial resistant genes}

Resistant genes for tetracyclines tet $A$, tet $B$, tet $C$, tet $D$, tet $E$ and tet $G$ were present in few isolates. $26 \%$ (6), $13 \%$ (3), $4 \%$ (1), of the isolates carried tet $A$, tet $B$, tet $D$ genes, respectively, and other tetracycline genes such as tet $C$, tet $E$ and tet $G$ were present in the $17 \%$ (4) of the isolates for each gene. While one of the resistance genes (sul3) for sulfonamides was absent in all the 23 isolates other two resistance genes for sulfonamides (sull and sul2) were present only in one of the isolates (4\%). All the resistance genes (catl, cat $2, \mathrm{cmlA}$, $\mathrm{cmlB}, \mathrm{floR}$ ) checked for chloramphenicol were absent in the isolates except cat3 which was present in one isolate (S6; 4\%). aac (3) 11a, one of the genes for aminoglycoside resistance was present in one isolate (4\%), 11 a aph (3) and aac6 were harbored by two isolates ( $9 \%$ for each gene) (Table 05).

Resistance to antibiotics is a major burning public health problem in the world. Illnesses that were once easily treatable with antibiotics are becoming more difficult to cure due to the emergence of resistance to present generation 
drugs. Rapid annual development of antibiotic has become a significant problem (Angelo et al., resistance in nontyphoidal Salmonella serovars 2016; Davidson et al., 2018).

Table 04: $\quad$ Sensitivity of Salmonella isolates to different antibiotics.

\begin{tabular}{llllllllllllll}
\hline $\begin{array}{c}\text { Isolate } \\
\text { number }\end{array}$ & NIT & NA & C & AMP & PIT & COT & CIP & TE & CTX & MRP & K & GEN \\
\hline $1 \mathrm{~S}$ & $\mathrm{~S}$ & $\mathrm{~S}$ & $\mathrm{~S}$ & $\mathrm{~S}$ & $\mathrm{~S}$ & $\mathrm{~S}$ & $\mathrm{~S}$ & $\mathrm{~S}$ & $\mathrm{~S}$ & $\mathrm{~S}$ & $\mathrm{~S}$ & $\mathrm{~S}$ \\
$2 \mathrm{~S}$ & $\mathrm{~S}$ & $\mathrm{~S}$ & $\mathrm{~S}$ & $\mathrm{I}$ & $\mathrm{S}$ & $\mathrm{S}$ & $\mathrm{S}$ & $\mathrm{S}$ & $\mathrm{S}$ & $\mathrm{S}$ & $\mathrm{S}$ & $\mathrm{S}$ \\
$3 \mathrm{~S}$ & $\mathrm{~S}$ & $\mathrm{~S}$ & $\mathrm{~S}$ & $\mathrm{~S}$ & $\mathrm{~S}$ & $\mathrm{~S}$ & $\mathrm{~S}$ & $\mathrm{~S}$ & $\mathrm{~S}$ & $\mathrm{~S}$ & $\mathrm{~S}$ & $\mathrm{~S}$ \\
$4 \mathrm{~S}$ & $\mathrm{~S}$ & $\mathrm{~S}$ & $\mathrm{~S}$ & $\mathrm{~S}$ & $\mathrm{~S}$ & $\mathrm{~S}$ & $\mathrm{~S}$ & $\mathrm{~S}$ & $\mathrm{~S}$ & $\mathrm{~S}$ & $\mathrm{~S}$ & $\mathrm{~S}$ \\
$5 \mathrm{~S}$ & $\mathrm{~S}$ & $\mathrm{~S}$ & $\mathrm{~S}$ & $\mathrm{R}$ & $\mathrm{S}$ & $\mathrm{S}$ & $\mathrm{S}$ & $\mathrm{S}$ & $\mathrm{S}$ & $\mathrm{S}$ & $\mathrm{S}$ & $\mathrm{S}$ \\
$6 \mathrm{~S}$ & $\mathrm{I}$ & $\mathrm{S}$ & $\mathrm{S}$ & $\mathrm{R}$ & $\mathrm{S}$ & $\mathrm{S}$ & $\mathrm{S}$ & $\mathrm{S}$ & $\mathrm{S}$ & $\mathrm{S}$ & $\mathrm{S}$ & $\mathrm{S}$ \\
$7 \mathrm{~S}$ & $\mathrm{~S}$ & $\mathrm{~S}$ & $\mathrm{~S}$ & $\mathrm{~S}$ & $\mathrm{~S}$ & $\mathrm{~S}$ & $\mathrm{~S}$ & $\mathrm{~S}$ & $\mathrm{~S}$ & $\mathrm{~S}$ & $\mathrm{~S}$ & $\mathrm{~S}$ \\
$8 \mathrm{~S}$ & $\mathrm{~S}$ & $\mathrm{~S}$ & $\mathrm{~S}$ & $\mathrm{~S}$ & $\mathrm{~S}$ & $\mathrm{~S}$ & $\mathrm{~S}$ & $\mathrm{~S}$ & $\mathrm{~S}$ & $\mathrm{~S}$ & $\mathrm{~S}$ & $\mathrm{~S}$ \\
$9 \mathrm{~S}$ & $\mathrm{~S}$ & $\mathrm{~S}$ & $\mathrm{~S}$ & $\mathrm{~S}$ & $\mathrm{~S}$ & $\mathrm{~S}$ & $\mathrm{~S}$ & $\mathrm{~S}$ & $\mathrm{~S}$ & $\mathrm{~S}$ & $\mathrm{~S}$ & $\mathrm{~S}$ \\
$10 \mathrm{~S}$ & $\mathrm{I}$ & $\mathrm{S}$ & $\mathrm{S}$ & $\mathrm{I}$ & $\mathrm{S}$ & $\mathrm{S}$ & $\mathrm{S}$ & $\mathrm{S}$ & $\mathrm{S}$ & $\mathrm{S}$ & $\mathrm{S}$ & $\mathrm{S}$ \\
$11 \mathrm{~S}$ & $\mathrm{I}$ & $\mathrm{S}$ & $\mathrm{S}$ & $\mathrm{S}$ & $\mathrm{S}$ & $\mathrm{S}$ & $\mathrm{S}$ & $\mathrm{S}$ & $\mathrm{S}$ & $\mathrm{S}$ & $\mathrm{S}$ & $\mathrm{S}$ \\
$12 \mathrm{~S}$ & $\mathrm{I}$ & $\mathrm{S}$ & $\mathrm{S}$ & $\mathrm{I}$ & $\mathrm{S}$ & $\mathrm{S}$ & $\mathrm{S}$ & $\mathrm{S}$ & $\mathrm{S}$ & $\mathrm{S}$ & $\mathrm{S}$ & $\mathrm{S}$ \\
$13 \mathrm{~S}$ & $\mathrm{~S}$ & $\mathrm{~S}$ & $\mathrm{~S}$ & $\mathrm{~S}$ & $\mathrm{~S}$ & $\mathrm{~S}$ & $\mathrm{~S}$ & $\mathrm{~S}$ & $\mathrm{~S}$ & $\mathrm{~S}$ & $\mathrm{~S}$ & $\mathrm{~S}$ \\
$14 \mathrm{~S}$ & $\mathrm{~S}$ & $\mathrm{~S}$ & $\mathrm{~S}$ & $\mathrm{~S}$ & $\mathrm{~S}$ & $\mathrm{~S}$ & $\mathrm{~S}$ & $\mathrm{~S}$ & $\mathrm{~S}$ & $\mathrm{~S}$ & $\mathrm{~S}$ & $\mathrm{~S}$ \\
$15 \mathrm{~S}$ & $\mathrm{~S}$ & $\mathrm{~S}$ & $\mathrm{~S}$ & $\mathrm{~S}$ & $\mathrm{~S}$ & $\mathrm{~S}$ & $\mathrm{~S}$ & $\mathrm{~S}$ & $\mathrm{~S}$ & $\mathrm{~S}$ & $\mathrm{~S}$ & $\mathrm{~S}$ \\
$16 \mathrm{~S}$ & $\mathrm{~S}$ & $\mathrm{~S}$ & $\mathrm{~S}$ & $\mathrm{~S}$ & $\mathrm{~S}$ & $\mathrm{~S}$ & $\mathrm{~S}$ & $\mathrm{~S}$ & $\mathrm{~S}$ & $\mathrm{~S}$ & $\mathrm{~S}$ & $\mathrm{~S}$ \\
$17 \mathrm{~S}$ & $\mathrm{~S}$ & $\mathrm{~S}$ & $\mathrm{~S}$ & $\mathrm{~S}$ & $\mathrm{~S}$ & $\mathrm{~S}$ & $\mathrm{~S}$ & $\mathrm{~S}$ & $\mathrm{~S}$ & $\mathrm{~S}$ & $\mathrm{~S}$ & $\mathrm{~S}$ \\
$18 \mathrm{~S}$ & $\mathrm{~S}$ & $\mathrm{~S}$ & $\mathrm{~S}$ & $\mathrm{R}$ & $\mathrm{S}$ & $\mathrm{S}$ & $\mathrm{S}$ & $\mathrm{S}$ & $\mathrm{S}$ & $\mathrm{S}$ & $\mathrm{S}$ & $\mathrm{S}$ \\
$19 \mathrm{~S}$ & $\mathrm{~S}$ & $\mathrm{~S}$ & $\mathrm{~S}$ & $\mathrm{~S}$ & $\mathrm{~S}$ & $\mathrm{~S}$ & $\mathrm{~S}$ & $\mathrm{~S}$ & $\mathrm{~S}$ & $\mathrm{~S}$ & $\mathrm{~S}$ & $\mathrm{~S}$ \\
$20 \mathrm{~S}$ & $\mathrm{I}$ & $\mathrm{S}$ & $\mathrm{S}$ & $\mathrm{S}$ & $\mathrm{S}$ & $\mathrm{S}$ & $\mathrm{S}$ & $\mathrm{S}$ & $\mathrm{I}$ & $\mathrm{S}$ & $\mathrm{S}$ & $\mathrm{S}$ \\
$21 \mathrm{~S}$ & $\mathrm{I}$ & $\mathrm{S}$ & $\mathrm{S}$ & $\mathrm{I}$ & $\mathrm{S}$ & $\mathrm{S}$ & $\mathrm{S}$ & $\mathrm{S}$ & $\mathrm{S}$ & $\mathrm{S}$ & $\mathrm{S}$ & $\mathrm{S}$ \\
$22 \mathrm{~S}$ & $\mathrm{I}$ & $\mathrm{S}$ & $\mathrm{S}$ & $\mathrm{I}$ & $\mathrm{S}$ & $\mathrm{S}$ & $\mathrm{S}$ & $\mathrm{S}$ & $\mathrm{S}$ & $\mathrm{S}$ & $\mathrm{S}$ & $\mathrm{S}$ \\
$23 \mathrm{~S}$ & $\mathrm{~S}$ & $\mathrm{~S}$ & $\mathrm{~S}$ & $\mathrm{~S}$ & $\mathrm{~S}$ & $\mathrm{~S}$ & $\mathrm{~S}$ & $\mathrm{~S}$ & $\mathrm{~S}$ & $\mathrm{~S}$ & $\mathrm{~S}$ & $\mathrm{~S}$ \\
\hline
\end{tabular}

${ }^{*} S$ indicates, sensitivity, I indicates intermediate sensitivity and $R$ indicates resistance to antibiotic nitrofurantoin (NIT), cefotaxime (CTX), nalidixic acid (NA), chloramphenicol (C), Ampicillin (AMP), piperacillin (PIT), co-trimozole (COT), ciprofloxacin (CIP), tetracycline (TE), meropenem (MRP), Kanamycin (K) and Gentamycin (GEN)

Table 05: $\quad$ Presence of antibiotic resistance genes in Salmonella isolates.

\begin{tabular}{|c|c|c|c|c|c|c|c|c|c|c|c|c|c|c|c|c|c|c|c|c|c|c|c|}
\hline \multirow{2}{*}{$\begin{array}{c}\text { Resistant } \\
\text { genes }\end{array}$} & \multicolumn{23}{|c|}{ Salmonella isolates } \\
\hline & S1 & S2 & S3 & S4 & S5 & S6 & S7 & S8 & S9 & $\begin{array}{c}\mathrm{S} \\
10 \\
\end{array}$ & $\begin{array}{c}\mathrm{S} \\
11 \\
\end{array}$ & $\begin{array}{c}S \\
12 \\
\end{array}$ & $\begin{array}{c}S \\
13 \\
\end{array}$ & $\begin{array}{c}\mathrm{S} \\
14 \\
\end{array}$ & $\begin{array}{cc}\mathrm{S} \\
15 \\
\end{array}$ & $\begin{array}{c}S \\
16 \\
\end{array}$ & $\begin{array}{c}S \\
17 \\
\end{array}$ & $\begin{array}{c}\mathrm{S} \\
18 \\
\end{array}$ & $\begin{array}{c}S \\
19 \\
\end{array}$ & $\begin{array}{c}\mathrm{S} \\
20 \\
\end{array}$ & $\begin{array}{c}\mathrm{S} \\
21 \\
\end{array}$ & $\begin{array}{c}\mathrm{S} \\
22 \\
\end{array}$ & $\begin{array}{c}\mathrm{S} \\
23 \\
\end{array}$ \\
\hline tetA & - & - & - & + & + & + & - & - & - & - & - & + & - & - & - & + & - & - & - & - & - & + & - \\
\hline tetB & - & - & - & - & + & - & + & - & - & - & + & - & - & - & - & - & - & - & - & - & - & - & - \\
\hline tet $C$ & - & - & - & + & - & - & - & - & - & - & + & - & - & - & - & - & + & - & - & - & - & + & - \\
\hline $\operatorname{tet} D$ & - & - & - & + & - & - & - & - & - & - & - & - & - & - & - & - & - & - & - & - & - & - & - \\
\hline tetE & - & - & - & - & - & + & - & - & - & - & - & + & - & - & - & - & - & - & - & - & - & + & + \\
\hline $\operatorname{tet} G$ & + & - & - & + & - & + & - & - & - & - & - & - & - & - & - & - & - & - & - & - & - & - & + \\
\hline Sull & - & - & - & - & - & - & - & - & - & - & - & - & - & - & - & - & - & - & - & - & - & - & + \\
\hline Sul2 & - & - & - & - & - & - & - & - & - & - & - & - & + & - & - & - & - & - & - & - & - & - & - \\
\hline Sul3 & - & - & - & - & - & - & - & - & - & - & - & - & - & - & - & - & - & - & - & - & - & - & - \\
\hline cat1 & - & - & - & - & - & - & - & - & - & - & - & - & - & - & - & - & - & - & - & - & - & - & - \\
\hline cat 2 & - & - & - & - & - & - & - & - & - & - & - & - & - & - & - & - & - & - & - & - & - & - & - \\
\hline cat3 & - & - & - & - & - & + & - & - & - & - & - & - & - & - & - & - & - & - & - & - & - & - & - \\
\hline cmlA & - & - & - & - & - & - & - & - & - & - & - & - & - & - & - & - & - & - & - & - & - & - & - \\
\hline $\mathrm{cmlB}$ & - & - & - & - & - & - & - & - & - & - & - & - & - & - & - & - & - & - & - & - & - & - & - \\
\hline floR & - & - & - & - & - & - & - & - & - & - & - & - & - & - & - & - & - & - & - & - & - & - & - \\
\hline aac (3)11a & - & - & - & + & - & - & - & - & - & - & - & - & - & - & - & - & - & - & - & - & - & - & - \\
\hline$a p h(3) 11 a$ & - & - & - & - & + & - & - & - & - & - & - & - & - & - & - & - & - & + & - & - & - & - & - \\
\hline aac6 & - & - & - & - & - & - & - & + & - & - & - & - & - & - & - & - & - & & - & - & + & - & - \\
\hline
\end{tabular}

Tetracycline (tetA, tetB, tetC, tetD, tetE and tet $G$ ), Sulfonamides (sul1, sul2, and sul3), Chloramphenicol (cat1, cat2, and cat3, cmlA, $\mathrm{cmlB}$, floR) and Aminoglycosides (aph (3)11a, aac (3)11a and aac6) 
In a similar study aimed at examining the prevalence and antimicrobial resistance of Salmonella isolates from broiler chickens, pigs and their associated meat products revealed that the multidrug resistance was $34 \%$ in Thailand and $52 \%$ in Cambodia. In accordance with the findings of the present study, the majority of the Thai isolates were also resistant to ampicillin (72.4\%). However, most Cambodian isolates were resistant to sulfamethoxazole (71\%) (Trongjit et al., 2017) giving different results from the present study where there was no resistant showed to the cotrimazole, the same group antibiotic with sulfamethoxazole. Obtaining similar results to the present study, Xia et al., (2009) in the USA showed that most of the Salmonella isolates in broiler chicken meat were susceptible to 15 commonly used antibiotics. In agreement with the present study, Moawad et al., (2017) in Egypt found that $S$. enterica isolated from chicken meat showed higher resistant to ampicillin but all were vulnerable to chloramphenicol as well as ciprofloxacin. A Study from Spain revealed that $60 \%$ of the total Salmonella isolates were resistant to minimum of one antibiotic and $20 \%$ were resistant to more than one antibiotic. Showing the same results as in the present study, all Salmonella spp. were susceptible to gentamicin, cefotaxime, kanamycin, ciprofloxacin and trimethoprim (cotrimozole) in that study too. However, in contrast to the present study, a high level of resistance has been observed in that study against nalidixic acid (Lamas et al., 2016). Furthermore, in a study conducted on prevalence and antimicrobial resistance profiles of Salmonella serotypes isolated from broiler chicken meat in Republic of Korea also revealed that the isolates were often resistant to different antibiotics including $85 \%$ to nalidixic acid (Kim et al., 2012). The above published data is also in contrast with the findings of the present study as all the tested isolates were sensitive to nalidixic acid in this study. Im et al., (2015) revealed that Salmonella isolates displayed resistance to ampicillin, tetracycline, gentamicin and nalidixic acid. However, in the current study, isolates displayed $13.5 \%$ resistance only to ampicillin and all the isolates were sensitive to nalidixic acid, tetracyclines and gentamicin. Prevalence and antimicrobial resistance patterns of Salmonella isolated from poultry farms in the United States were carried out by Velasquez et al., (2018) and resistance to gentamycin was not observed while resistance to chloramphenicol was observed at a low level. The present study showed that Salmonella isolated from Sri Lanka were sensitive to both gentamycin and chioramphenicol. It is an interesting finding that local Salmonella have not yet developed resistance against chloramphenicol, which is one of the limited number of antibiotics that can be used to treat typhoid fever in human.

Despite to the increasing incidence of ciproflioxacin resistant Salmonella in some countries (Threlfall et al., 2002; Medalla et al., 2013) several studies have found that there is a decreasing tendency of developing resistance in Salmonella against few antibiotics and it is in agreement with the findings of the current study. For instance, Davidson et al., (2018) have found no isolate resistant to ciprofloxacin among total of 242 Salmonella isolates. In other studies too, monitoring Salmonella isolates have shown that there was no resistance to ciprofloxacin and nalidixic acid (Cummings et al., 2013; Davidson et al., 2018). A study conducted on Salmonella enterica isolated from 4976 clinical samples observed parallel findings that showed a tendency for gradual declining of resistance for gentamicin, trimethoprim as well as neomycin (Valenzuela et al., 2017). Mąka et al., (2015) also showed that Salmonella spp. isolated from non meat food items were fully sensitive to many commonly used antibiotics, but some were resistant to chloramphenicol. Though it is reported that $S$. Enteritidis is relatively more susceptible to commonly used antibiotics than $S$. Typhimurium (Barilli et al., 2018), it was not clearly shown in the present study. Out of the three isolates that displayed resistance against ampicillin, only one isolate (S6) belongs to $S$. Typhimurium serotype whereas other two isolates were non-serotyped.

The results of the present study have shown that most of the Salmonella isolates exhibited a high level of sensitivity to most of the tested antibiotics. Although that message is gratifying, antimicrobial susceptibility must be assessed continuously and conduct more extensive work to identify the whole picture on antibiotic resistance in Salmonella in the livestock sector in the country in order to make a general conclusion. 


\section{CONCLUSIONS}

The present study concluded the presence of Salmonella spp. in broiler chicken meat in Sri Lanka during the investigation period and the $S$. Typhimurium is the most common organism followed by $S$. Enteritidis. Further, it can be concluded that there is a low prevalence of antibiotic resistance among the isolates, nevertheless, the detection of intermediate resistance to antimicrobial agents in many isolates could predict the possibility of developing and spread of multidrug resistance strains in the future.

\section{ACKNOWLEDGMENT}

The financial support by the Higher Education for the $21^{\text {st }}$ Century (HETC) project of the Ministry of Higher Education, Sri Lanka through the scholarship SUSL/O-Agri/N1 to the study is gratefully acknowledged. The assistance of the staff of the Livestock Production Laboratory of the Faculty of Agricultural Sciences of the Sabaragamuwa University of Sri Lanka and UNESCO MIRCEN for Marine Biotechnology, Nitte University, Mangalore, India is highly appreciated.

\section{Conflicts of interest}

The authors declare that there is no conflict of interests.

\section{REFERENCES}

Abatcha, M.G., Effarizah, M.E. and Rusul, G. (2018). Prevalence, antimicrobial resistance, resistance genes and class 1 integrons of Salmonella serovars in leafy vegetables, chicken carcasses and related processing environments in Malaysian fresh food markets. Food Control. 91, pp.170 180.doi:10.1016/j.foodcont.2018.02.039

Abd El Tawwab, A.A., Ammar, A.M., Ali, A.R. El Hofy, F.I. and Ahmed, M.E.E. (2013). Detection of common $(\operatorname{InvA})$ gene in Salmonellae isolated from poultry using polymerase chain reaction technique. Benha Veterinary Medical Journal. 25, pp.70-77.

Abdellah, C., Filali Fouzia, R., Abdelkader, C., Bencheikh Rachida, S. and Mouloud, Z. (2009). Prevalence and anti-microbial susceptibility of Salmonella isolates from chicken carcasses and giblets in Meknès, Morocco. African Journal of Microbiology Research. 3(5): 215- 219.

Andino, A. and Hanning, I. (2015). Salmonella enterica: Survival, Colonization, and Virulence Differences among Serovars. Scientific World Journal. Pp. 1-16. doi.org/10.1155/2015/520179

Andrews, W.H. and Hammack, T. (2011). Salmonella. In: Bacteriological Analytical Manual, Food and Drug Administration, AOAC Int. pp. 1322-1324.

Angelo, K.M., Reynolds, J., Karp, B.E., Hoekstra, R.M., Scheel, C.M. and Friedman, C. (2016). Antimicrobial Resistance Among Nontyphoidal Salmonella Isolated From Blood in the United States, 2003-2013. The Journal of Infectious Diseases. 214(10):pp.1565-70. https://doi. org/10.1093/infdis/jiw415 PMID: 27609807 
Ariyawansa, S., Ginigaddarage, P., Jinadasa, K., Chandrika, J. M., Ganegama Arachchi, G., and Ariyaratne, S. (2016). Assessment of microbiological and biochemical quality of fish in a supply chain in Negombo, Sri Lanka. Procedia Food Science. 6, pp.246-252. doi.org/10.1016/j. profoo.2016.02.032

Ausubel, F., Brent, R., Kingston, R.E., Moore, D.D., Seidman, J.G., Smith, J.A. and Struhl, K. (Eds.) (1992). In: Current Protocols in Molecular Biology.2nd Edition. Unit. 2.4. Green Publications Associations, New York.

Barilli, E., Bacci, C., and StellaVilla, Z. (2018). Antimicrobial resistance, biofilm synthesis and virulence genes in Salmonella isolated from pigs bred on intensive farms. Italian Journal of Food Safety. 2(7):p.7223. doi:10.4081/ijfs.2018.7223

Bauer, A.W., Kirby, W.M.M., Sherris, J. C. and Turck, M. (1966). Antibiotic susceptibility testing by a standardized single disk method. American Journal of Clinical Pathology. 36, pp.493-496.

Bhowmick, P.P., Shabarinath, S., Devananda, D., Shekar, M., Ruwandeepika, H.A.D., Karunasagar, I. and Karunasagar, I. (2012). Serotyping and molecular characterization for study of genetic diversity among non typhoidal Salmonella serovars. Indian Journal of Medical research. 135, pp.371-380.

Bhowmick, P.P, Devegowda, D., Ruwandeepika, H.A., Karunasagar, I and Karunasagar, I. (2011). Presence of Salmonella pathogenicity island 2 genes in seafood-associated Salmonella serovars and the role of the sseC gene in survival of Salmonella enterica serovar Weltevreden in epithelial cells. Microbiology. 157, pp.160-168. doi.org/10.1099/mic.0.043596-0

Bodhidatta, L., Srijan, A. and Serechatalergs, O. (2013). Bacterial pathogens isolated from raw meat and poultry compared with pathogens isolated from children in the same area of rural Thailand. Southeast Asian Journal of Tropical Medicine and Public Health. 44, pp.259-272.

Chotinun, S., Rojanasthien, S., Unger, F., Tadee, P. and Patchanee, P. (2014). Prevalence and antimicrobial resistance of Salmonella isolated from carcasses, processing facilities and the environment surrounding small scale poultry slaughterhouses in Thailand. Southeast Asian Journal of Tropical Medicine and Public Health. 45, pp.1392-1400.

Cossi, M.V., Burin, R.C., Lopes, D.A., Dias, M.R., Castilho, N.P., de Arruda Pintoand, P.S., and Nero, L.A. (2013). Antimicrobial resistance and virulence profiles of Salmonella isolated from butcher shops in Minas Gerais, Brasil. Journal of Food Protection. 76, pp.1633-1637. doi. org/10.4315/0362-028X.JFP-13-119

Cummings, K.J., Perkins, G.A., Khatibzadeh, S.M., Warnick, L.D., and Altier, C. (2013). Antimicrobial resistance trends among salmonella isolates obtained from dairy cattle in the northeastern United States, 2004-2011. Foodborne pathogens and disease. 10(4): pp.353-361. https://doi. org/10.1089/fpd.2012.1285 PMID: 23458026

DAPH, (2015). Annual Report of the Department of Animal Production and Health, Peradeniya, Sri Lanka.

Davidson, K.E., Byrne, B.A., Pires, A.F.A., Magdesian, K.G. and Pereira, R.V. (2018). Antimicrobial resistance trends in fecal Salmonella isolates from northern California dairy cattle admitted to a veterinary teaching hospital, 2002-2016. PLoS ONE 13(6): e0199928. https://doi.org/10.1371/ journal. pone. 0199928 
Dissanayake, D.R.A., Wijewardana, T.G., Gunawardena, G.A. and Poxton, I.R. (2008). Distribution of lipopolysaccharide core types among avian pathogenic Escherichia coli in relation to the major phylogenetic groups. Veterinary microbiology. 132(3-4), pp.355-363. https://doi.org/10.1016/j. vetmic.2008.05.024

Dominguez, C., Gomez, I. and Zumalacarregui, J.(2002). Prevalence of Salmonella and Campylobacter in retail chicken meat in Spain. International Journal of Food Microbiology, 72(1-2): pp.165168. https://doi.org/10.1016/S0168-1605(01)00638-9

EFSA(European Food Safety Authority). ECDC (European centre for disease prevention and control). (2015). The European Union summary report on trends and sources of zoonoses, zoonotic agents and food-borne outbreaks in 2013. European Food Safety Journal. 13(1): p.3991.

EFSA European Food Safety Authority and European Centre for Disease Prevention and Control (ECDC) (2016). The European Union summary report on trends and sources of zoonoses, zoonotic agents and food-borne outbreaks in 2015. European Food Safety Journal. 14(12): p.4634. doi: $10.2903 /$ j.efsa.2016.4634

El-Aziz, D.M.A. (2013). Detection of Salmonella typhimurium in retail chicken meat and chicken giblets. Asian Pacific journal of tropical biomedicine. 3(9): pp.678-681. doi: 10.1016/S22211691(13)60138-0

El-Sebay, N. A., Hala Mohamed Abu Shady, Seham Abd El-Rashed El-Zeedy and Samy, A.A. (2017). invA Gene Sequencing of Salmonella typhimurium Isolated from Egyptian Poultry. Asian Journal of Scientific Research. 10, Pp. 194-202. doi.10.3923/ajsr.2017.194.202.

Farzan,A., Frienship, R.M., Cook, A. and Pollari, F. (2010). Occurrence of Salmonella, Campylobacter, Yersinia enterocolitica, Escherichia coli $\mathrm{O} 157$ and Listeria monocytogenes in swine. Zoonoses Public Health. 57, pp.388-396. doi.org/10.1111/j.1863-2378.2009.01248.x

Ibrahim, W.A., Abd El Ghany, W.A., Nasef, S.A. and Hatem, M.E. (2014). A comparative study on the use of real time polymerase chain reaction (RT-PCR) and standard isolation techniques for the detection of Salmonellae in broiler chicks. International Journal of Veterinary Science and Medicine. 2, pp.67-71. doi.org/10.1016/j.ijvsm.2013.11.001

Im, M.C., Jeong, S.J., Kwon, Y.K., Jeong, O.M., Kang, M.S. and Lee, Y.J. (2015). Prevalence and characteristics of Salmonella spp. isolated from commercial layer farms in Korea. Poultry Science. 94, pp.1691-1698. http://dx.doi.org/10.3382/ps/pev137

Issenhuth-Jeanjean, S., Roggentin, P., Mikoleit, M., Guibourdenche, M., de Pinna, E., Nair, S., Fields, P.I. and Weill, F.X. (2014). Supplement 2008-2010 (no. 48) to the White-KauffmannLe Minor scheme. Research in microbiology. 165(7): pp.526-530. https://doi.org/10.1016/j. resmic.2014.07.004

Jalali, M., Abedi, D., Pourbakhsh, S.A. and Ghoukasin, K. (2008). Prevalence of salmonella spp. in raw and cooked foods in Isfahan-Iran. Journal of food safety, 28(3): pp.442-452. https://doi. $\operatorname{org} / 10.1111 / \mathrm{j} .1745-4565.2008 .00122 . x$

Jones, D.D., Law, R. and Bej, A.K. (1993). Detection of Salmonella spp. in oysters using Polymerase chain reaction (PCR) and gene probes. Journal of Food Science. 58, pp.1191-1197. doi. $\operatorname{org} / 10.1111 / \mathrm{j} .1365-2621.1993 . t b 06146 . x$ 
Kamalika, J., Ubeyratne, H., Kleer, J., Hildebrandt, G., Fries, R., Khattiya, R. and Zessin, K.H. (2008). Prevalence of Salmonella in marketed Penaeus monodon shrimps in North Western Province, Sri Lanka. Berliner Und Munchener Tierarztliche Wochenschrift. 121, pp.418-421.

Karatug, N.T., Yüksel, F.N., Akçelik, N. and Akçelik, M. (2018). Genetic diversity of food originated Salmonella isolates. Biotechnology \& Biotechnological Equipment. 32(3): pp.638-645. doi: 10.1080/13102818.2018.1451779

Karmi, M. (2013). Detection of virulence gene (invA) in Salmonella isolated from meat and poultry products. International Journal of Genetics. 3(2): pp. 7-12. DOI: 10.5829/idosi. ijg.2013.3.2.82204

Kim, M.S., Lim, T.H., Jang, J.H., Lee, D.H., Kim, B.Y., Kwon, J.H., Choi, S.W., Noh, J. Y., Hong, Y.H., Lee, S.B., Yang, S.Y., Lee, H.J., Lee, J.B., Park, S.Y., Choi, I.S. and Song, C.S. (2012). Prevalence and antimicrobial resistance of Salmonella species isolated from chicken meats produced by different integrated broiler operations in Korea. Poultry Science. 91, 2370-2375. http://dx.doi.org/ 10.3382/ps.2012-02357

Kottawatta, K.S.A., Bandara, J.M.K.V., Thilakarathne, D.S., Rajapaksha, D.I.G., Abeynayake, P. and Kalupahana, R.S. (2014). Occurrence of motile salmonella in broiler flocks and antimicrobial susceptibility patterns of isolates. Proceedings of the Peradeniya Univ. International Research Sessions, Sri Lanka. 18, p.187.

Kottawatta, K.S., Van Bergen, M.A., Abeynayake, P., Wagenaar, J.A., Veldman, K.T. and Kalupahana, R.S. (2017). Campylobacter in broiler chicken and broiler meat in Sri Lanka: Influence of semiautomated vs. wet market processing on campylobacter contamination of broiler neck skin samples. Foods. 6(12): p.105. https://doi.org/10.3390/foods6120105

Kulasooriya, G.D.B.N., Amarasiri, M.K.U.T., Abeykoon, A.M.H. and Kalupahana, R.S. (2019). Salmonella, Campylobacter and Escherichia coli in raw chicken meat, chicken products and cooked chicken in retail markets in Kandy, Sri Lanka. Sri Lanka Veterinary Journal. 66(1): pp.19-26.

Lamas, A., Miranda, J.M., Regal, P., Vázquez, B., Franco C.M and Cepeda, A. (2018). A comprehensive review of non-enterica subspecies of Salmonella enteric. Poultry Science. 206, pp.60-73. https:// doi.org/10.1016/j.micres.2017.09.010

Lamas, A., Fernandez-No, I. C., Miranda, J. M., Vázquez, B., Cepeda, A. and Franco, C. M. (2016). Prevalence, molecular characterization and antimicrobial resistance of Salmonella serovars isolated from northwestern Spanish broiler flocks (2011-2015). Poultry Science. 95(9): pp. 2097-2105. https://doi.org/10.3382/ps/pew150

Litrup, E., Torpdahl, M., Malorny, B., Huehn, S., Helms, M., Christensen, H. and Nielsen, E.M. (2010). Association between phylogeny, virulence potential and serovars of Salmonella enteric Infection. Genetics and Evolution. 10(7): pp.1132-1139. doi:10.1016/j.meegid.2010.07.015

Ma, M., Wang, H., Yu, Y., Zhang, D. and Liu, S. (2007). Detection of antimicrobial resistance genes of pathogenic Salmonella from swine with DNA microarray. Journal of Veterinary Diagnostic Investigation. 19, pp.161-167. doi.org/10.1177/104063870701900204

Magwedere, K., Rauff, D., De Klerk, G., Karen, H., Keddy, F.D. (2015). Incidence of Nontyphoidal Salmonella in Food-Producing Animals, Animal Feed, and the Associated Environment in South Africa, 2012-2014. Clinical Infectious Diseases. 61(4): pp. 283289.. https://doi.org/10.1093/cid/civ663. 
Majowicz, S.E., Musto, J., Scallan, E., Angulo, F.J., Kirk, M. and O’Brien, S.J. (2010). The global burden of non typhoidal Salmonella gastroenteritis. Clinical Infectious Diseases. 50 (6): pp.882889. doi: 10.1086/650733. https://doi.org/10.1086/650733

Mąka, L., Maćkiw, E., Ścieżyńska, H. and Popowska, M. (2015). Occurrence and antimicrobial resistance of Salmonella spp. isolated from food other than meat in Poland. Annals of Agricultural and Environmental Medicine. 22(3): pp.403-408. doi:10.5604/12321966.1167701

Medalla, F., Hoekstra, R.M., Whichard, J.M., Barzilay, E.J., Chiller, T.M., Joyce, K., Rickert, R., Krueger, A., Stuart, A. and Griffin, P.M. (2013). Increase in resistance to ceftriaxone and nonsusceptibility to ciprofloxacin and decrease in multidrug resistance among Salmonella strains, United States, 1996-2009. Foodborne pathogens and disease, 10(4): pp.302-309..

Mir, I.A., Kashyap, S.K. and Maherchandani, S. (2015). Isolation, serotype diversity and antibiogram of Salmonella enterica isolated from different species of poultry in India. Asian Pacific Journal of Tropical Biomedicine. 5, pp.561-567. https://doi.org/10.1016/j.apjtb.2015.03.010

Moawad, A.A., Hotzel, H., Awad, O., Tomaso, H., Neubauer, H., Hafez, H.M. and El-Adawy, H. (2017). Occurrence of Salmonella enterica and Escherichia coli in raw chicken and beef meat in northern Egypt and dissemination of their antibiotic resistance markers. Gut pathogens. 9(1): p.57.

Nidaullah, H., Abirami, N. and Shamila-Syuhada, A.K. (2017). Prevalence of Salmonella in poultry processing environments in wet markets in Penang and Perlis, Malaysia. Veterinary World. 10(3): pp.286-292. doi:10.14202/vetworld. 286-292.

Osman, K.M., Marouf, S.H., Zolnikov, T.R.A. and Atfeehy, N. (2014). Isolation and characterization of Salmonella enterica in day-old ducklings in Egypt. Pathogens and Global Health. 108(1): pp. 37-48. https://doi.org/10.1179/2047773213Y.0000000118

Parvej, S., Rahman, M., Uddin, F., Nazir, N.H., Jowel, S., Khan, F.R. and Rahman, B. (2016). Isolation and characterization of Salmonella enterica serovar typhimurium circulating among healthy chickens of Bangladesh. Turkish Journal of Agriculture Food Science and Technology. 4(5): pp.519-523. https://doi.org/10.24925/turjaf.v4i7.519-523.695

Rahn, K., Degrandis, S.A., Clarke, R.C., Mcewen, S.A.,Galan, J.E., Ginocch, O.C., Curtiss, R. and Gyles, C.L. (1992). Amplification of an invA gene sequence of Salmonella Typhimurium by polymerase chain reaction as a specific method of detection of Salmonella. Molecular and Cellular Probes. 6, pp.271-279. doi.org/10.1016/0890-8508 (92)90002-F

Ryan, M.P., O'Dwyer, J. and Adley, C.C. (2017). Evaluation of the complex nomenclature of the clinically and veterinary significant pathogen Salmonella. BioMed research international, 2017. https://doi.org/10.1155/2017/3782182

Shanmugasamy, M., Velayutham T. and Rajeswar, J. (2011). inv A gene specific PCR for detection of Salmonella from broilers. Veterinary World. 4, pp.562-564. doi: 10.5455/vetworld.2011.562-564

Thilakarathne, D. S., Kottawatta, K. S. A., Kalupahana, R. S. and Abeynayake, P. (2012). Investigation of Campylobacter, Salmonella, Escherichia coli and staphylococcus aureus in chicken meat at small scale retail shops in kandy city limits. Annual Scientific Sessions of the Sri Lanka Veterinary Association, 11 May 2012, p.13. 
Threlfall, E.J., Skinner, J.A., Graham, A., Ward, L.R. and Smith, H.R. (2000). Resistance to ceftriaxone and cefotaxime in non-typhoidal Salmonella enterica in England and Wales. Journal of Antimicrobial Chemotherapy. 46, pp.860-862.

https://doi.org/10.1093/jac/46.5.860

Trongjit, S., Angkititrakul, S., Tuttle, R.E., Poungseree, J., Padungtod, P. and Chuanchuen, R. (2017). Prevalence and antimicrobial resistance in Salmonella enterica isolated from broiler chickens, pigs and meat products in Thailand-Cambodia border provinces. Microbiology and Immunology. 61, pp.23-33. doi: 10.1111/1348-0421.12462

Turki, Y., Mehri, I. and Fhoula, I. (2014). Comparison of five molecular subtyping methods for differentiation of Salmonella Kentucky isolates in Tunisia. World Journal of Microbiology and Biotechnology. 30, pp.87-98. doi: 10.1007/s11274-013-1414-1.

Uyttendaele, M., De Troy, P. and Debevere, J. (1999). Incidence of Listeria monocytogenes in different types of meat products on the Belgian retail market. International journal of food microbiology. 53(1): pp.75-80. https://doi.org/10.1016/S0168-1605(99)00155-5

Valenzuela, J.R., Sethi, A.K., Aulik, N.A. and Poulsen, K.P. (2017). Antimicrobial resistance patterns of bovine Salmonella enterica isolates submitted to the Wisconsin Veterinary Diagnostic Laboratory: 2006-2015. Journal of Dairy Science. 100(2):1319-1330. https://doi.org/10.3168/ jds.2016-11419 PMID: 28012630

Velasquez, C.G., Macklin, K.S., Kumar, S., Bailey, M., Ebner, P.E., Oliver, H.F., Martin-Gonzalez, F.S. and Singh, M. (2018). Prevalence and antimicrobial resistance patterns of Salmonella isolated from poultry farms in southeastern United States, Poultry Science. 97 (6): pp.2144-2152. https:// doi.org/10.3382/ps/pex449

Weerasooriya, K.M.S.G., Kalupahana, R.S. and Abeynayake, P. (2008). Occurrence of Salmonella contamination in poultry meat. Proceedings of the Peradeniya University research Sessions, Sri Lanka. Volume 13, 18 ${ }^{\text {th }}$ December 2008.

Wijemanne, L.M.P., Wimalasiri, S. R. and Wijewardana, T.G. (2008). Isolation and Identification of Salmonella from Poultry Breeder Reactors. (In) Proceedings of the $10^{\text {th }}$ Annual Scientific Sessions of World's Poultry Science Association- Sri Lankan Branch held in Colombo on Dec 6, 2008.

Xia, X., Zhao, S., Smith, A., McEvoy, J., Meng, J. and Bhagwat, A.A. (2009). Characterization of Salmonella isolates from retail foods based on serotyping, pulse field gel electrophoresis, antibiotic resistance and other phenotypic properties. International journal of food microbiology. 129(1): pp.93-98. https://doi.org/10.1016/j.ijfoodmicro.2008.11.007

Yildirim, Y., Gonulalan, Z., Pamuk, S. and Ertas, N. (2011). Incidence and antibiotic resistance of Salmonella spp. on raw chicken carcasses. Food Research International. 44(3): pp.725-728. https://doi.org/10.1016/j.foodres.2010.12.040

Zdragas, A., Mazaraki, K., Vafeas, G., Giantzi, V., Papadopoulos, T. and Ekateriniadou, L. (2012). Prevalence, seasonal occurrence and antimicrobial resistance of Salmonella in poultry retail products in Greece. Letters in applied microbiology. 55(4): pp.308-313. https://doi.org/10.1111/ j.1472-765X.2012.03298.x 
Zhao, S., White, D.G., Ge, B., Ayers, S., Friedman, S., English, L., Wagner, D., Gaines, S. and Meng, J. (2001). Identification and characterization of integron-mediated antibiotic resistance among Shiga toxin-producing Escherichia coli isolates. Applied Environmental Microbiology. 67(4): pp.1558-1564. doi: 10.1128/AEM.67.4.1558-1564.2001 